\title{
Glucoregulatory and Anti-Inflammatory Activities of Peptide Fractions Separated by Electrodialysis with Ultrafiltration Membranes from Salmon Protein Hydrolysate and Identification of Four Novel Glucoregulatory Peptides
}

\author{
Loïc Henaux $^{1,2}$, Karina Danielle Pereira ${ }^{3,4}$, Jacinthe Thibodeau ${ }^{1,2}$, Geneviève Pilon ${ }^{2,5}$, Tom Gill ${ }^{6}$ (D), \\ André Marette ${ }^{2,5}$ and Laurent Bazinet $1,2, *$ (D)
}

1 Department of Food Sciences and Laboratory of Food Processing and Electromembrane Processes (LTAPEM), Université Laval, Quebec City, QC G1V 0A6, Canada; loic.henaux.1@ulaval.ca (L.H.); jacinthe.thibodeau.1@ulaval.ca (J.T.)

2 Institute of Nutrition and Functional Foods (INAF), University Laval, Quebec City, QC G1V 0A6, Canada; genevieve.pilon@criucpq.ulaval.ca (G.P.); andre.marette@criucpq.ulaval.ca (A.M.)

3 Laboratory of Biotechnology, School of Applied Sciences, University of Campinas (UNICAMP), Limeira 13484-350, SP, Brazil; kdp.thomaz@gmail.com

4 Institute of Biosciences, State University (UNESP), Rio Claro 13506-900, SP, Brazil

check for updates

Citation: Henaux, L.; Pereira, K.D.; Thibodeau, J.; Pilon, G.; Gill, T.; Marette, A.; Bazinet, L.

Glucoregulatory and Anti-Inflammatory Activities of Peptide Fractions Separated by Electrodialysis with Ultrafiltration Membranes from Salmon Protein Hydrolysate and Identification of Four Novel Glucoregulatory Peptides. Membranes 2021, 11, 528. https:// doi.org/10.3390/membranes11070528

Academic Editor: João G. Crespo

Received: 18 June 2021

Accepted: 9 July 2021

Published: 14 July 2021

Publisher's Note: MDPI stays neutral with regard to jurisdictional claims in published maps and institutional affiliations.

Copyright: (c) 2021 by the authors. Licensee MDPI, Basel, Switzerland. This article is an open access article distributed under the terms and conditions of the Creative Commons Attribution (CC BY) license (https:// creativecommons.org/licenses/by/ $4.0 /)$.
5 Department of Medicine, Faculty of Medicine, Quebec Heart and Lung Institute Cardiology Group, Université Laval, 2725 Chemin Ste-Foy, Quebec City, QC G1V 4G5, Canada

6 Department of Process Engineering and Applied Science, Dalhousie University, P.O. Box 15000, Halifax, NS B3H 4R2, Canada; Tom.Gill@dal.ca

* Correspondence: laurent.bazinet@fsaa.ulaval.ca; Tel.: +1-418-656-2131 (ext. 407445)

\begin{abstract}
Natural bioactive peptides are suitable candidates for preventing the development of Type 2 diabetes (T2D), by reducing the various risk factors. The aim of this study was to concentrate glucoregulatory and anti-inflammatory peptides, from salmon by-products, by electrodialysis with ultrafiltration membrane (EDUF), and to identify peptides responsible for these bioactivities. Two EDUF configurations ( 1 and 2) were used to concentrate anionic and cationic peptides, respectively. After EDUF separation, two fractions demonstrated interesting properties: the initial fraction of the EDUF configuration 1 and the final fraction of the EDUF configuration 2 both showed biological activities to (1) increase glucose uptake in L6 muscle cells in insulin condition at $1 \mathrm{ng} / \mathrm{mL}$ (by $12 \%$ and $21 \%$, respectively), (2) decrease hepatic glucose production in hepatic cells at $1 \mathrm{ng} / \mathrm{mL}$ in basal (17\% and $16 \%$, respectively), and insulin ( $25 \%$ and $34 \%$, respectively) conditions, and (3) decrease LPS-induced inflammation in macrophages at $1 \mathrm{~g} / \mathrm{mL}$ (45\% and 30\%, respectively). More impressive, the initial fraction of the EDUF configuration 1 ( $45 \%$ reduction) showed the same effect as the phenformin at $10 \mu \mathrm{M}(40 \%)$, a drug used to treat T2D. Thirteen peptides were identified, chemically synthesized, and tested in-vitro for these three bioactivities. Thus, four new bioactive peptides were identified: IPVE increased glucose uptake by muscle cells, IVDI and IEGTL decreased hepatic glucose production (HGP) of insulin, whereas VAPEEHPTL decreased HGP under both basal condition and in the presence of insulin. To the best of our knowledge, this is the first time that (1) bioactive peptide fractions generated after separation by EDUF were demonstrated to be bioactive on three different criteria; all involved in the T2D, and (2) potential sequences involved in the improvement of glucose uptake and/or in the regulation of HGP were identified from a salmon protein hydrolysate.
\end{abstract}

Keywords: electrodialysis with filtration membrane; salmon protein hydrolysate; bioactive peptides; anti-inflammatory activity; glucose uptake; hepatic glucose production

\section{Introduction}

Type 2 diabetes (T2D) mellitus is a complex metabolic disorder and progressive disease [1]. T2D is associated with environmental causes and behavioral changes as overeating, 
smoking, physical inactivity, excessive alcohol, and "junk" food consumption [2]. According to the World Health Organization (WHO), non-communicable diseases (including T2D) are the world's biggest killers. Indeed, annually, more than 36 million people die from NCDs (63\% of global deaths) [3]. Moreover, according to a recent report from the International Diabetes Federation, in 2019, 463 million of people aged between 20 to 79 years had the T2D, [4]. Nevertheless, in order to prevent NCDs and T2D, promoting healthy diet and physical activity are an integral part of the WHO's "Global action plan for the prevention and control of non-communicable diseases 2013-2020" [3]. However, a high proportion of people at risk do not follow these recommendations, and the T2D continues to progress [5].

Increased fish consumption has been suggested to improve the metabolic syndrome (MetS), to reduce the incidence of T2D, and to protect against cardiovascular disease (CVD) in obese subjects [6,7]. Besides the well documented beneficial effects of the high concentration of omega-3 polyunsaturated fatty acids (PUFA) found in various fish sources, many observations suggest that omega-3 PUFA are not the sole player involved in the beneficial properties of fish consumption on MetS. Indeed, a meta-analysis revealed that daily intake of as much as $3 \mathrm{~g}$ of fish oil alone has no beneficial effect on glycemia in T2D [8], while consumption of whole lean fish (24 g/day; providing only $140 \mathrm{mg}$ of $\omega-3$ fatty acid) was inversely correlated with the incidence of insulin resistance and T2D [9]. These latter findings are consistent with the hypothesis that a constituent other than lipid was responsible for the beneficial effect of fish consumption on glucose metabolism. In the last decade, studies carried out on animals and humans revealed that fish protein can improve insulin sensitivity and reduce obesity-linked inflammation [10-15]. More recently, it was found that a salmon protein hydrolysate reduces body fat and increases insulin sensitivity [16]. Protein hydrolysates from salmon and other fish sources (mackerel, bonito, and herring) were also found to reduce inflammation in visceral adipose tissue [16]. These observations are consistent with previous studies showing that dietary fish protein improves insulin sensitivity and reduces inflammation in insulin-resistant subjects [14,15]. Moreover, the fractionation of salmon protein hydrolysate suggested that low molecular weight peptides $(<1 \mathrm{kDa})$ were highly responsible for those bioactivities [17]. However, the identification of these bioactive peptides (BPs) has never been accomplished. Consequently, BPs are suitable candidates for a new era of pharmaceutical products, especially with the heightened concerns of side effects of small molecule drugs [18]. Nevertheless, BPs are fragments that are encrypted in the primary sequences of proteins, conferring functions beyond basic nutritional benefit [19]. Because these peptides are generated by protein hydrolysis, they can represent only minor constituents in a highly complex matrix, further separation steps are needed to concentrate these peptides and optimize their bioactive effects [20].

Hence, very recently, the efficiency of electrodialysis with ultrafiltration membrane (EDUF) to generate bioactive fractions from a complex hydrolysate such as a salmon byproduct hydrolysate, was demonstrated [21]. In fact, in this study, it was observed that anionic peptides concentrated in all three anionic recovery compartments (ARC1, ARC2 and ARC3) could increase the glucose uptake in basal condition. Moreover, it was also observed that the initial hydrolysate, when depleted in cationic peptides, also showed an increase of the glucose uptake, as well as the fraction in basal condition was able to mimic the insulin action and demonstrated the same efficiency to increase the glucose uptake than insulin control. Nevertheless, in the previous study by our team [21], the bioactive properties were focused only on the glucose uptake, whereas T2D is characterized by the defective insulin secretion from pancreatic beta cell resulting from an effort to compensate for various abnormalities such as hepatic insulin resistance and an impaired muscle glucose uptake associated to a chronic inflammatory state [22].

In this context, the study aimed to generate bioactive fractions against T2D and to identify peptide sequences responsible for these bioactivities. Hence, three bioactivities were studied, such as glucose uptake, hepatic glucose production (HGP) and anti-inflammatory properties. Furthermore, the most promising sequences were chemically synthetized and 
individually tested for their capacity to increase glucose uptake, to decrease HGP and to decrease inflammation.

\section{Materials and Methods}

\subsection{Materials and Electrodialysis Cell}

\subsubsection{Hydrolysate Preparation}

The salmon protein hydrolysate $(\mathrm{SPH})$ was produced according to the procedure described previously by Chevrier et al. [17]. Briefly, deboned salmon frames were homogenized in a $1.0 \mathrm{M} \mathrm{NaOH}$ solution before isoelectric precipitation. Then, a sequential hydrolysis was carried out with pepsin, then trypsin and chymotrypsin. The supernatant was filtered through a $5 \mu \mathrm{m}$ pore size paper filter to remove any insoluble fat or protein and, afterwards, the filtrate was ultrafiltered using a Prep/Scale Tangential Flow Filtration (TFF) $2.5 \mathrm{ft}^{2}$ cartridge with $1 \mathrm{kDa}$ size-exclusion limit (Millipore Corporation, Bedford, MA, USA). The permeates containing peptides with molecular weights $<1 \mathrm{kDa}$ were collected, demineralized by electrodialysis and freeze-dried.

\subsubsection{Chemicals}

$\mathrm{Na}_{2} \mathrm{SO}_{4}$ from Laboratoire MAT (Quebec City, QC, Canada), 1.0 M NaOH and HCl solutions as well as acetonitrile optima ${ }^{\circledR}$ LC/MS were provided from Fisher Scientific (Montréal, QC, Canada). Trifluoroacetic acid (TFA) was obtained from J.T. Baker (Phillipsburg, NJ, USA) and $\mathrm{KCl}$ was purchased from ACP Inc (Montreal, QC, Canada). Fetal Bovine Serum (FBS) and trypsin (0.25\% solution) were obtained from Invitrogen (Burlington, ON, Canada). Nylon filters were from Mandel Scientific (Guelph, ON, Canada). 2-déoxy-Dglucose (nonradioactive), $\mathrm{CaCl}_{2}$, Hepes-Na and $\mathrm{MgSO}_{4}$ were obtained from Sigma Aldrich (Oakville, ON, Canada), $\mathrm{NaCl}$ from VWR international (Montreal, QC, Canada). D-2-deoxy$[3 \mathrm{H}]$ glucose (radioactive) from Perkin Elmer (Woodbridge, ON, Canada). Finally, Pierce ${ }^{\circledR}$ BCA Protein Assay Kit BCA, from Pierce Biotechnology (Rockford, IL, USA).

\subsubsection{Peptide Synthesis}

Peptide synthesis and purification were carried out by the Laboratoire de chimie peptidique et biomoléculaire du CHU de Québec (Québec, QC, Canada). Peptides were synthesized by standard Fmoc solid-phase synthesis using 1-Cl-Trt resin [23,24]. A purity level of $\geq 90 \%$ for each sequence was achieved. Briefly, the Fmoc protecting group was removed from the resin by two 10 min treatments with $20 \%$ piperidine in dimethylformamide (DMF, $v / v)$, and amino acid coupling was performed with Fmoc- Xaa-OH (3 equivalents), 1-(6-Chloro-1H-benzotriazole-1-yl)-1,1,3,3-tetramethylaminium hexafluorophosphate (HCTU, 3 equivalents) and N-methylmorpholine (12 equivalents) in dimethylformamide (DMF, $2 \times 30 \mathrm{~min}$ ). The synthesized peptides were released by treating the resin with 20\% hexafluoro-1-propanol (HFIP) in dichloromethane (DCM) during $30 \mathrm{~min}$ [25]. Side chain deprotection was achieved by treating the peptides with TFA/triisopropylsilane (TIPS) $/ \mathrm{H}_{2} \mathrm{O}(95: 2.5: 2.5, v / v / v)$ during $3 \mathrm{~h}$ prior to precipitation with cold ether and purification by RP-HPLC (Shimadzu Prominence instrument (Columbia, MD, USA)) using a Vydac 218 MS column $(300 \AA 22.0 \times 250 \mathrm{~mm}, 10 \mu \mathrm{m}, \mathrm{C} 18)$ with a $0.1 \% \mathrm{TFA} / \mathrm{H}_{2} \mathrm{O}$ (solvent A) and $0.1 \%$ TFA $/ \mathrm{CH}_{3} \mathrm{CN}$ (solvent B) linear gradient of $10-100 \%$ solvent $\mathrm{B}$ for 20 min at a flow rate of $10 \mathrm{~mL} / \mathrm{min}$ and UV detection at $220 \mathrm{~nm}$ and $254 \mathrm{~nm}$. Freeze-dried purified peptides were characterized by a hybrid ion mobility quadrupole TOF mass spectrometer (6560 high-definition mass spectrometry (IM-Q-TOF), Agilent, Santa Clara, CA, USA).

Before being tested in-vitro, the chemically synthesized peptides were simply diluted in HPLC grade water at a $1 \mathrm{mg} / \mathrm{mL}$ concentration and the mother solution was diluted with a specific volume of culture medium to obtain the final desired concentration to be tested and to be added with the cells. The control was the same volume of culture medium added to the cells. 


\subsubsection{Membranes}

For EDUF, one polyether sulfone (PES) ultrafiltration membrane with a molecular weight cut-off of $50 \mathrm{kDa}$ was purchased from Synder filtration (Vacaville, CA, USA). Food grade Neosepta CMX-SB cationic membranes as well as Neosepta AMX-SB anionic membranes were obtained from Astom (Tokyo, Japan).

\subsubsection{Electrodialysis Configurations}

The electrodialysis cell used for the experiments was an MP type cell with an effective surface area of $100 \mathrm{~cm}^{2}$, manufactured by ElectroCell Systems AB Company (Täby, Sweden). The cell was composed of one anion-exchange membrane (AEM), one cation-exchange membranes (CEM), one ultrafiltration membrane (UFM) with MWCO $50 \mathrm{kDa}$ as illustrated in Figure 1 and as described in [21].
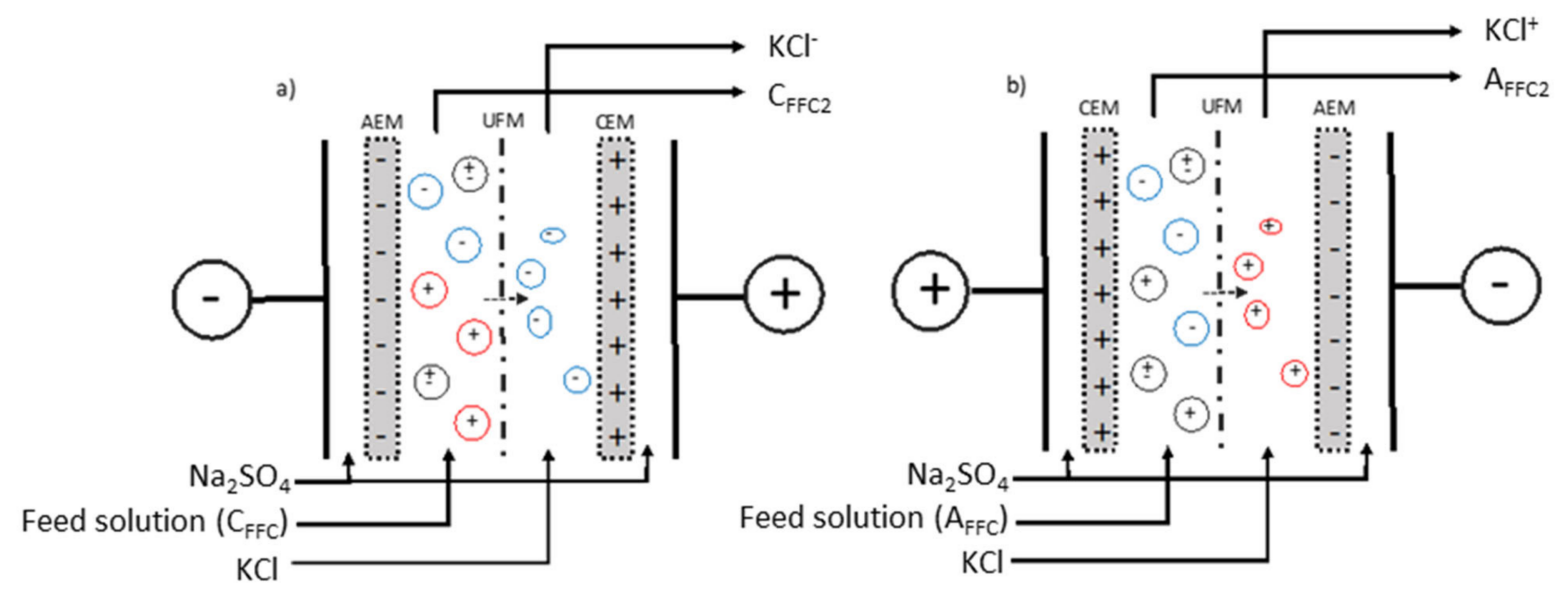

Figure 1. Schematic of electrodialysis with ultrafiltration membrane (EDUF) cells: (a) configuration 1-for the fractionation of $\mathrm{C}_{\mathrm{FFC}}$ (Cationic final feed compartment), and (b) configuration 2-for the fractionation of $\mathrm{A}_{\mathrm{FFC}}$ (Anionic final feed compartment), generated from a previous work [21].

The first configuration - configuration 1 (Figure 1a) was arranged for the separation of anionic peptides. The cell was divided into three closed loops; one contained $1.5 \mathrm{~L}$ of a $\mathrm{KCl}$ solution $(2 \mathrm{~g} / \mathrm{L})$ for the recovery and concentration of anionic peptides $\left(\mathrm{KCl}^{-}\right)$. The feed solution consisting of the Cationic Final Feed Compartment $\left(\mathrm{C}_{\mathrm{FFC}}\right)$ generated from a previous EDUF separation [21] was circulated in the compartment between the UFM and AEM. The recovery solution from the feed compartment was called $\mathrm{C}_{\mathrm{FFC} 2}$. The last loop contained the electrode rinsing solution $\left(20 \mathrm{~g} / \mathrm{L}, \mathrm{Na}_{2} \mathrm{SO}_{4}, 3 \mathrm{~L}\right)$, split into two streams circulating into both electrolyte compartments.

In the second configuration-configuration 2 (Figure 1b), the compartment con- taining a $\mathrm{KCl}$ solution circulating between the UFM and AEM allowed the recuperation of cationic peptides $\left(\mathrm{KCl}^{+}\right)$. The feed solution was circulated in the compartment between the UFM and CEM. The feed solution consisting of the Anionic Final Feed Compartment $\left(A_{F F C}\right)$ generated from a previous EDUF separation [21], and the final solution recovered in this compartment was called $\mathrm{A}_{\mathrm{FFC} 2}$. The rinsing electrode solution was circulated into both electrode compartments as for the anionic configuration.

\subsubsection{Electroseparation Protocol}

The spray dried SPH was diluted with deionized water at a protein concentration of $0.7 \%(w / v)$ and the EDUF fractionation was performed for $4 \mathrm{~h}$. EDUF experiments were carried out in batches for both cell configurations at a constant electrical field strength of $6 \mathrm{~V} / \mathrm{cm}$ (corresponding to a current density varying between 0.005 and $0.008 \mathrm{~A} / \mathrm{cm}^{2}$ during the treatment). The system temperature was maintained around $16{ }^{\circ} \mathrm{C}$ to prevent microbial growth [26]. The EDUF separations were done at $\mathrm{pH} 6$, the same $\mathrm{pH}$ used in our previous 
study. Indeed, in that study, the final solution recovered in the feed compartment enhanced the glucose uptake at $1 \mathrm{ng}$ and $1 \mu \mathrm{g} / \mathrm{mL}$ in both conditions (basal and stimulated by insulin), and the cationic peptides recovered in the Cationic Recovery Compartment (CRC) stimulated the bioactivity under the basal condition at both $1 \mathrm{ng}$ and $1 \mu \mathrm{g} / \mathrm{m}$ [21]. From these results, the $\mathrm{pH}^{\prime}$ s of SPH and recovery $(\mathrm{KCl})$ solutions were adjusted to 6 before each run with $0.1 \mathrm{~N} \mathrm{NaOH}$ and/or $0.1 \mathrm{~N} \mathrm{HCl}$ and maintained constant thereafter [21]. For each treatment, volumes of $10 \mathrm{~mL}$ of SPH and recovery solutions were collected before applying voltage, and then every hour during the treatment to determine the peptide migration rate and their kinetics of migration. The electrical conductivity of the SPH feedstock and recovery solutions was kept constant by the addition of $\mathrm{KCl}$, as seen in Suwal et al. [26]. The current intensity and electrical potential differences of the AEM, CEM and UFMs were recorded every 30 min during EDUF experiments for both configurations. Finally, for each condition, 3 replicates were carried out. A cleaning-in-place procedure was performed after each replicate, according to the membrane manufacturer's instructions and the cell was dismantled before being reassembled.

\subsection{In-Vitro Experiments and Analyses}

\subsubsection{Glucose Uptake Experiments}

Glucose uptake experiments were performed as previously described by Henaux et al. [21], Roblet et al. [27] and Tremblay et al. [28]. Briefly, L6 skeletal muscle cells were grown in an $\alpha$-minimum essential medium ( $\alpha$-MEM) containing $2 \%(v / v)$ fetal bovine serum (GBS) in an atmosphere of $5 \% \mathrm{CO}_{2}$ at $37^{\circ} \mathrm{C}$. Cells were plated at 600,000 cells / plate in 24-well plates to obtain about 25,000 cells $/ \mathrm{mL}$. The cells were incubated 7 days, to reach their complete differentiation to myotubes (7 days post-plating). A volume of $10 \mu \mathrm{L}$ of EDUF fractions has been tested at a concentration of $1 \mu \mathrm{g} / \mathrm{mL}$ and $1 \mathrm{ng} / \mathrm{mL}$, and synthesized peptides at a concentration of $1 \mathrm{ng} / \mathrm{mL}$. After experimental treatments, cells were rinsed once with $37^{\circ} \mathrm{C}$ HEPES-buffered solution (20 mM HEPES, $\mathrm{pH} 7.4,140 \mathrm{mM}$ $\mathrm{NaCl}, 5 \mathrm{mM} \mathrm{KCl}, 2.5 \mathrm{mM} \mathrm{MgSO}_{4}$, and $1 \mathrm{mM} \mathrm{CaCl}_{2}$ ) and were subsequently incubated in HEPES-buffered solution containing $10 \mu \mathrm{M}$ 2-deoxyglucose and $0.3 \mu \mathrm{Ci} / \mathrm{mL}$ 2-deoxy-[$\left[{ }^{3} \mathrm{H}\right]$ glucose for $8 \mathrm{~min}$. The radioactivity was determined by scintillation counting. Protein concentrations were determined by the BCA method, and glucose uptake results were expressed in pmol/min.mg of protein. The experiments were repeated 6 times, and each repetition was run in triplicate.

\subsubsection{Hepatic Glucose Production Experiments}

Hepatic glucose production experiments were performed as described by Chevrier et al. [17] with EDUF fractions or synthesized peptides at a concentration of $10 \mu \mathrm{L} /$ well with or without insulin at 1 and $0.1 \mathrm{nmol}$, respectively. Briefly, FAO rat hepatocytes were grown and maintained in monolayer culture in Roswell Park Memorial Institute medium (RPMI) containing $10 \%$ FBS in an atmosphere of $5 \% \mathrm{CO}_{2}$ at $37^{\circ} \mathrm{C}$. Cells were plated at $4 \times 10^{6}$ cells/plate. FAO cells were deprived with $1 \mathrm{~mL} /$ well of RPMI without FBS, and the EDUF's fractions were added at $10 \mu \mathrm{L} /$ well with or without insulin at $1 \mathrm{nmol}$. Cells were washed three times with PBS, then incubated for $5 \mathrm{~h}$ (in an atmosphere of $5 \% \mathrm{CO}_{2}$ at $37^{\circ} \mathrm{C}$ ) with EDUF fractions at a concentration of 1 and $1 \mathrm{ng} / \mathrm{mL}$, or with the synthesized peptides at a concentration of $1 \mathrm{ng} / \mathrm{mL}$, in the presence or absence of insulin at $1 \mathrm{nmol}$ in a hepatic glucose production medium. Glucose production was measured in the medium by using the Amplex Red Glucose/Glucose Oxidase Assay kit (Invitrogen, Waltham, MA, USA). Experiments were repeated 6 times, and each repetition was run in triplicate.

\subsubsection{Anti-Inflammatory Experiments}

Anti-inflammatory experiments were conducted as described by Chevrier et al. [17]. Cells were plated at $4 \times 10^{6}$ cells/plate for $24 \mathrm{~h}$ before the experiment, macrophages were stimulated with $2.5 \mathrm{ng} / \mathrm{mL}$ of lipopolysaccharide (LPS) in the presence of EDUF fractions at a concentration of 1 and $1 \mathrm{ng} / \mathrm{mL}$, or synthesized peptides at $1 \mathrm{ng} / \mathrm{mL}$ for $16 \mathrm{~h}$, 
and the accumulation of nitrite was used as an index of inducible NO synthase. Nitrite was measured by using the Griess method. Then, cells were lysed in $50 \mathrm{mmol} \mathrm{NaOH}$, and protein content was determined by using BCA protein Assay kit. Experiments were repeated 6 times with the EDUF fractions and 3 times with the synthesized peptides, and each repetition was run in triplicate.

\subsubsection{Total Peptide Concentration in Dry Samples}

The total nitrogen content was measured by the combustion of around $100 \mathrm{mg}$ of sample powder (LECO-FP528 carbon nitrogen analyzer, LECO, St. Joseph, MI, USA) in order to obtain the final concentration of peptide in each peptide recovery compartment $\left(\mathrm{KCl}^{+}, \mathrm{KCl}^{-}, \mathrm{A}_{\mathrm{FFC} 2}\right.$ and $\left.\mathrm{C}_{\mathrm{FFC} 2}\right)$ as well as in initial $\left(\mathrm{C}_{\mathrm{FFC}}\right.$ and $\left.\mathrm{A}_{\mathrm{FFC}}\right)$ feed solutions. The nitrogen concentration obtained in the samples was converted into peptide percentage by multiplying with a conversion factor of 6.25 , the value commonly used for crude fish proteins.

\subsubsection{RP-UPLC and Mass Spectrometry Analyses}

The RP-UPLC analyses were done according to the previous study from Henaux et al. [21] and Durand et al. [29] with a 1290 Infinity II UPLC (Agilent Technologies, Santa Clara, CA, USA) to separate samples before entering the mass spectrometer. All EDUF fractions were diluted at the same peptide concentration of $0.5 \mathrm{mg} / \mathrm{mL}$ (based on LECO total nitrogen determination) to allow comparison of the peptide area under the curve. Then the samples were filtered through $0.22 \mu \mathrm{m}$ PVDF filter into a glass vial. A volume of $5 \mu \mathrm{L}$ of each sample was loaded onto an Acquity UPLC CSH $1301.7 \mu \mathrm{m}$ C18 column (2.1 mm i.d. $\times 150 \mathrm{~mm}$, Waters Corporation, Milford, MA, USA) at $400 \mu \mathrm{L} / \mathrm{min}$ and $45^{\circ} \mathrm{C}$. A linear gradient from $2 \%$ to $25 \%$ over 50 min and ramping to $90 \%$ until $57 \mathrm{~min}$ was used. The gradient was composed of solvent A (LC-MS grade water with $0.1 \%$ formic acid), and solvent B (LC-MS grade ACN with $0.1 \%$ formic acid). Each sample was run in triplicate for statistical evaluation of technical reproducibility.

A hybrid ion mobility quadrupole TOF mass spectrometer (6560 high-definition mass spectrometry (IM-Q-TOF), Agilent, Santa Clara, CA, USA) was used to identify the composition of each EDUF fraction. The method was identical as Henaux et al. [21]. The Salmonidae protein database was used to search and identified potential peptides.

\subsubsection{Statistical Analyses}

In-vitro bioactivity assays (Glucose uptake, hepatic glucose production and antiinflammatory experiments) were subjected to a one-way analysis of variance (ANOVA) using SAS software version 9.1 (SAS institute Inc., Cary, NC, USA) with Dunnett's post hoc test at a significant $p$ value of 0.05 for acceptance. Peak areas of the chromatograms have been compared using a one-way analysis of variance (ANOVA) using SAS software version 9.1 (SAS institute Inc., Cary, NC, USA) with Tukey's post hoc tests at a significant $p$ value of 0.05 for acceptance.

\section{Results and Discussion}

\subsection{Effects of EDUF Fractions}

3.1.1. Glucose Uptake

Glucose intolerance has been identified as a major metabolic abnormality involved in the metabolic syndrome and a diabetes precursor, resulting in a deficiency of insulin to mediate muscle glucose uptake and to inhibit hepatic glucose production [30]. In-vitro experiments on L6 myocytes were performed to investigate the glucoregulatory effect of EDUF fractions. As presented in Figure 2, no effect was observed in any of the fractions under the basal condition. However, some EDUF fractions were able to promote insulin activity on glucose uptake. As shown in Figure 2a, both $\mathrm{C}_{\mathrm{FFC} 2}$ and $\mathrm{KCl}^{-}$have significantly increased glucose uptake in the presence of insulin stimulation at $1 \mathrm{ng} / \mathrm{mL}$ of $21 \%$ and 
$15 \%$, respectively, while the initial fraction, $\mathrm{C}_{\mathrm{FFC}}$, showed no effect on the bioactivity. $\mathrm{C}_{\mathrm{FFC} 2}$ is deprived in anionic peptides, while $\mathrm{C}_{\mathrm{FFC}}$ contains all anionic peptides.

Concerning the EDUF configuration 2, only the initial fraction $\left(\mathrm{A}_{\mathrm{FFC}}\right)$ demonstrated an enhancement (12\%) of glucose uptake in presence of insulin stimulation (Figure $2 b$ ). The final fraction $\left(\mathrm{A}_{\mathrm{FFC} 2}\right)$ showed no effect, and the recovered fraction, $\mathrm{KCl}^{+}$, concentrated in cationic peptides, had significantly decreased glucose uptake at $1 \mu \mathrm{g} / \mathrm{mL}$ in presence of insulin stimulation. Thus, these results suggested a potential antagonistic effect of down-regulation between peptides and inhibitory peptides which was canceled when peptides were separated into $\mathrm{KCl}^{+}$and $\mathrm{A}_{\mathrm{FFC} 2}$ fractions.

Nevertheless, because bioactive peptides are generated by protein hydrolysis, they can represent only minor constituents in a highly complex matrix, and the bioactivity could be altered due to inhibition or interaction among peptides [31]. The use of subsequent separation steps is needed to enrich active peptide fractions from the hydrolysates [32]. For example, Roblet et al. [33] managed to generate bioactive anionic and cationic fractions, from a non-bioactive hydrolysate, depending on the $\mathrm{pH}$ used for the separation $(3,6$ or 9$)$. However, at pH 6 (pH used in this study) they obtained a cationic fraction able to increase glucose uptake, while our cationic fraction $\mathrm{KCl}^{+}$showed a decrease. These different results can be explained by the different UFMs MWCO used for the separation $(20 \mathrm{kDa}$ instead of $50 \mathrm{kDa}$ in our study), generating fractions of different composition in terms of size and sequences [34,35].

Furthermore, it was demonstrated, in our previous study, that the anionic peptides from a salmon by-product hydrolysate were responsible for the improvement of the glucose uptake in L6 muscle cells, while cationic peptides may be inhibitors of this bioactivity [21]. Indeed, from our first simultaneous EDUF separation it was concluded that anionic peptides may be involved in the glucose uptake response as anionic peptides recovered in $A_{R C 1}$ (Anionic Recovery Compartment 1), $\mathrm{A}_{\mathrm{RC} 2}$ (Anionic Recovery Compartment 2) and $\mathrm{A}_{\mathrm{RC} 3}$ (Anionic Recovery Compartment 3 ) demonstrated a significant increase in glucose uptake at both $1 \mathrm{ng} / \mathrm{mL}$ and $1 \mu \mathrm{g} / \mathrm{mL}$ under basal conditions. On the other hand, Cationic Recovery Compartment $3\left(\mathrm{C}_{\mathrm{RC} 3}\right)$ from our previous study had decreased the bioactivity [21].
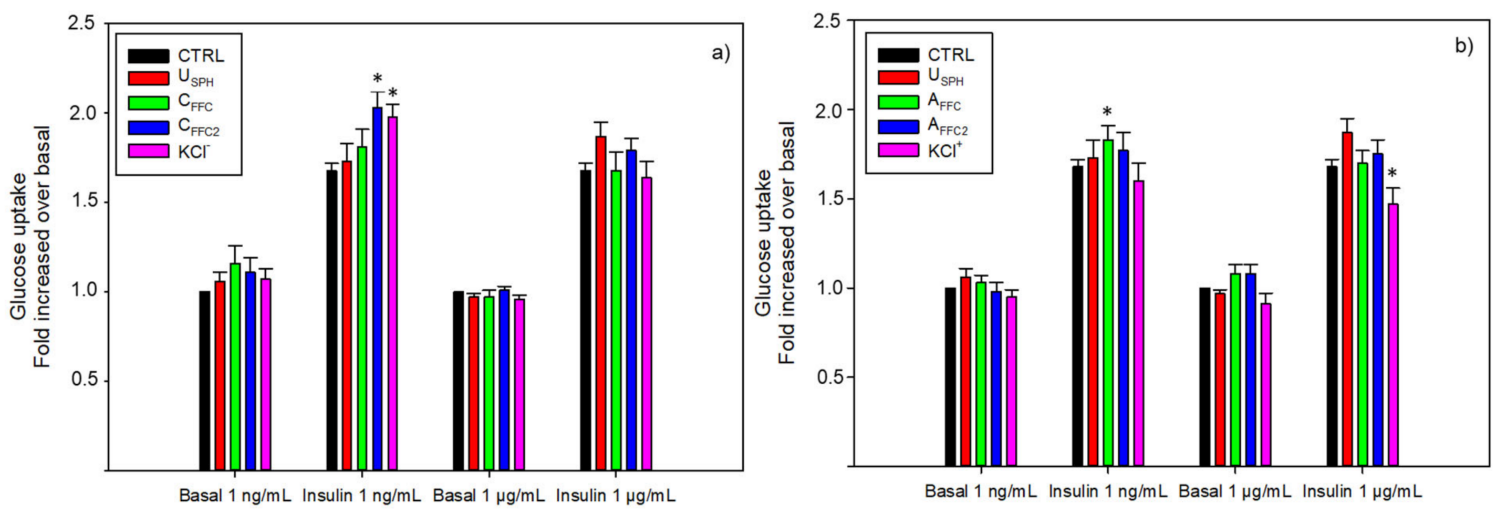

Figure 2. Glucose uptake modulation in L6 skeletal muscle cells with or without insulin stimulation by (a) the recovery compartments from EDUF configuration 1 and (b) the recovery compartments from EDUF configuration 2. Data represent mean $\pm \mathrm{SEM}, n=9$. An asterisk indicates that mean values are significantly different $(p<0.05)$ from the control's mean value.

In addition to peptides, free cationic amino acids could have reached the $\mathrm{KCl}^{+}$and decreased the bioactivity. It was previously demonstrated that free cationic amino acids, generated by the enzymatic hydrolysis of various marine by-products, for example snow crab by-products [36] or herring milt [29], could be concentrated in recovery compartments. Moreover, some of these cationic amino acids, such as histidine, cysteine and tyrosine have been identified as inhibitors of glucose uptake in presence of insulin stimulation [32]. The authors concluded that these amino acids may potentiate the activation of 
the mTOR/p70S6k pathway, that negatively modulates the ability of insulin to transmit signals to PI 3- kinase via IRS-1 and leading to an insulin resistance [28].

\subsubsection{Hepatic Glucose Production}

The capacity of the EDUF fractions to modulate basal and insulin hepatic glucose production (HGP) in FAO cells was investigated and results are presented in Figure 3. Once more, no effect was observed concerning the USPH. Nevertheless, as presented in Figure $3 \mathrm{a}, \mathrm{KCl}^{-}$fraction decreased the HGP in basal condition of 17 and $9 \%$ at $1 \mathrm{ng} / \mathrm{mL}$ and $1 \mu \mathrm{g} / \mathrm{mL}$, respectively. These anionic peptides recovered in the $\mathrm{KCl}^{-}$fraction have also improved the insulin effect on the HGP by $35 \%$ at $1 \mathrm{ng} / \mathrm{mL}$ compared to the insulin control. Finally, both fractions recovered in the feed compartments $\left(\mathrm{C}_{\mathrm{FFC}}\right.$ and $\left.\mathrm{C}_{\mathrm{FFC} 2}\right)$ were bioactive at both concentrations: $\mathrm{C}_{\mathrm{FFC}}$ decreased the HGP at the highest concentration tested $(1 \mu \mathrm{g} / \mathrm{mL})$ in basal $(11 \%)$ and insulin $(14 \%)$ conditions, whereas $\mathrm{C}_{\mathrm{FFC} 2}$ decreased HGP at the lowest concentration tested $(1 \mathrm{ng} / \mathrm{mL})$, also in basal $(16 \%)$ and insulin $(34 \%)$ conditions. Concerning the EDUF configuration 2 (Figure 3b), cationic peptides recovered in the $\mathrm{KCl}^{+}$fraction demonstrated the highest bioactivity in basal (28\%) and insulin (36\%) conditions at $1 \mathrm{ng} / \mathrm{mL}$, compared to control conditions. Moreover, $\mathrm{A}_{\mathrm{FFC}}$ also demonstrated a decrease in HGP (17 and $25 \%$ ) at $1 \mathrm{ng} / \mathrm{mL}$ (without and with insulin stimulation, respectively). Finally, $\mathrm{A}_{\mathrm{FFC} 2}$ decreased the HGP by $25 \%$ at $1 \mathrm{ng} / \mathrm{mL}$ comparatively to the insulin control.

For the first time, EDUF fractions demonstrated the capacity to decrease the HGP in in-vitro models. Indeed, the use of subsequent separation steps increased the concentration of bioactive peptides in fractions and generated bioactive fractions. Interestingly, both recovery compartment fractions, $\mathrm{KCl}^{-}$and $\mathrm{KCl}^{+}$, have shown the highest inhibition of the HGP compared to fractions from the feed compartment $\left(\mathrm{C}_{\mathrm{FFC}}\right.$ and $\mathrm{C}_{\mathrm{FFC} 2} ; \mathrm{A}_{\mathrm{FFC}}$ and $\mathrm{A}_{\mathrm{FFC} 2}$, respectively). Thus, charged peptides, able to cross the $50 \mathrm{kDa}$ UFM, were involved in the reduction of the hepatic glucose production. As the migration was not complete, peptides concentrated in the recovery compartments might still be present in the feed compartments, a single peptide or a group of peptides found in all fractions could induce this HGP decrease.
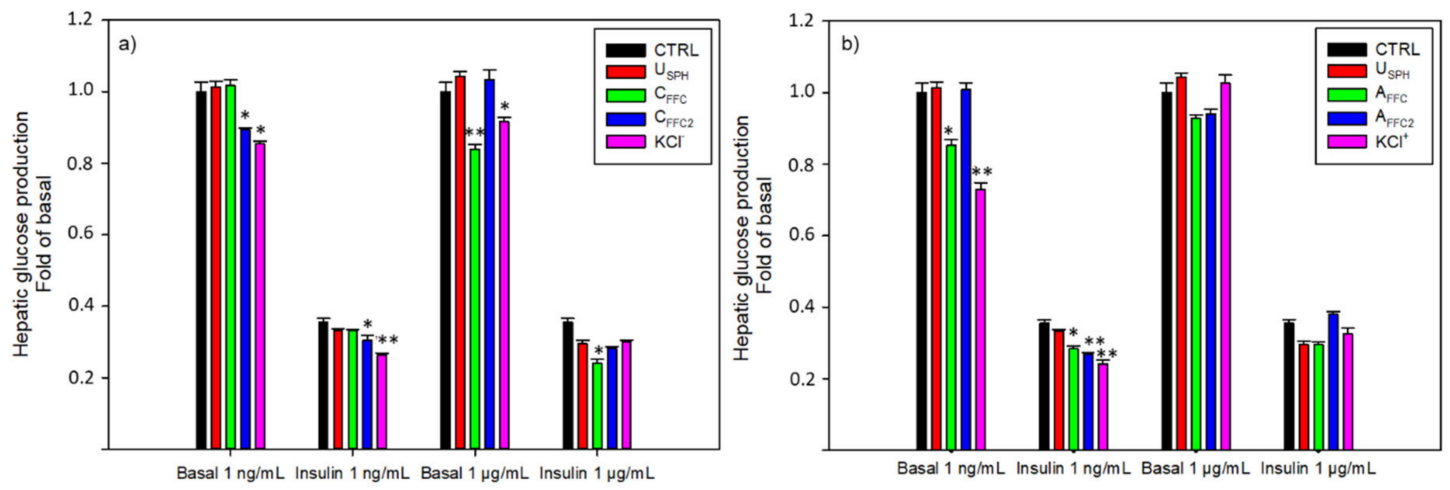

Figure 3. In-vitro hepatic production from FAO cells with or without insulin inhibition by (a) the recovery compartments from EDUF configuration 1 and (b) the recovery compartments from EDUF configuration 2. Data represent mean \pm SEM, $n=6$. An asterisk indicates that mean values are significantly different $(p<0.05)$ from the control's mean value.

\subsubsection{Inflammation}

In-vitro anti-inflammatory effects of EDUF fractions were investigated and results are presented in Figure 4. All fractions were tested in the presence of LPS, to observe a possible reduction of the LPS-induced inflammatory effect measured by nitrite accumulation as an index of NO production. Moreover, phenformin, an antidiabetic drug used for the treatment of T2D, was used as a positive control to compare the effect of EDUF fractions. As for previous bioactivities tested, the USPH did not show any effect on the inflammation 
(Figure 4). However, $\mathrm{C}_{\mathrm{FFC} 2}$, from EDUF configuration 1 decreased LPS-induced iNOS activation in macrophages by $30 \%$ at $1 \mu \mathrm{g} / \mathrm{mL}$ (Figure $4 \mathrm{a}$ ). Concerning configuration 2 (Figure $4 \mathrm{~b}), \mathrm{A}_{\mathrm{FFC}}$ decreased the inflammation at $1 \mu \mathrm{g} / \mathrm{mL}$. While $\mathrm{A}_{\mathrm{FFC} 2}(22$ and $27 \%$ ) and $\mathrm{KCl}^{+}(25$ and $18 \%$ ) have demonstrated a significant decrease in LPS-induced inflammation for both concentrations ( $1 \mathrm{ng} / \mathrm{mL}$ and $1 \mu \mathrm{g} / \mathrm{mL}$, respectively). Interestingly, $\mathrm{A}_{\mathrm{FFC}}$, at a concentration of $1 \mu \mathrm{g} / \mathrm{mL}$, yielded $45 \%$ of reduction in inflammation, showing the same effect as the phenformin at $10 \mu \mathrm{M}(40 \%)(p=0.558)$. These results demonstrated the in-vitro reduction in LPS-induced iNOS activation. The removal of some cationic peptides from the initial feed $\left(\mathrm{A}_{\mathrm{FFC}}\right)$ decreased the anti-inflammatory effect. Indeed, a decrease of the inflammation was observed in $\mathrm{A}_{\mathrm{FFC} 2}$ compared to $\mathrm{A}_{\mathrm{FFC}}$. However, as the experiments were carried out at the same concentrations ( $1 \mathrm{ng}$ and $1 \mathrm{ug} / \mathrm{mL}$ of peptides), the relative concentration of cationic peptides in $\mathrm{KCl}^{+}$was higher compared to $\mathrm{A}_{\mathrm{FFC}}$ and $\mathrm{A}_{\mathrm{FFC2}}$. Nevertheless, as previously explained, $\mathrm{A}_{\mathrm{FFC}}$ had a better activity than the $\mathrm{KCl}^{+}$. Thus, a synergistic effect might exist between cationic peptides and other peptides in $A_{F F C}$, resulting in a stronger anti-inflammatory effect than the one obtained for the isolated $\mathrm{KCl}^{+}$fraction.

a)

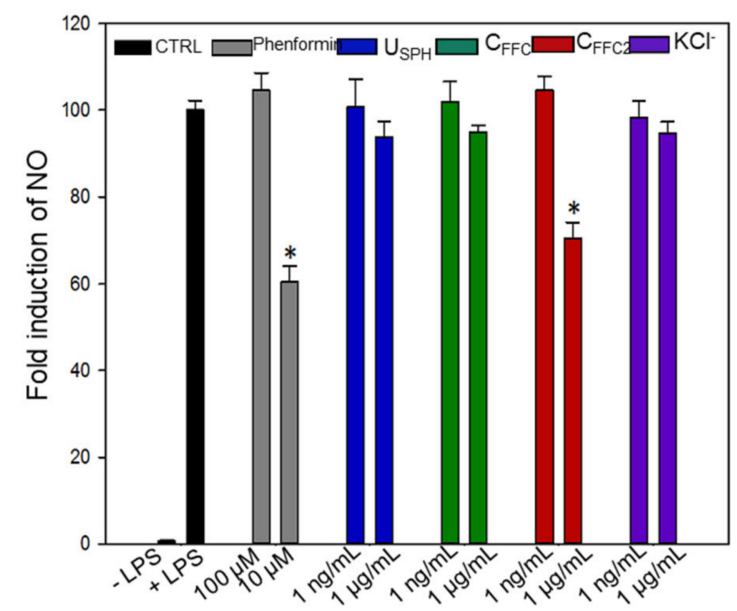

b)

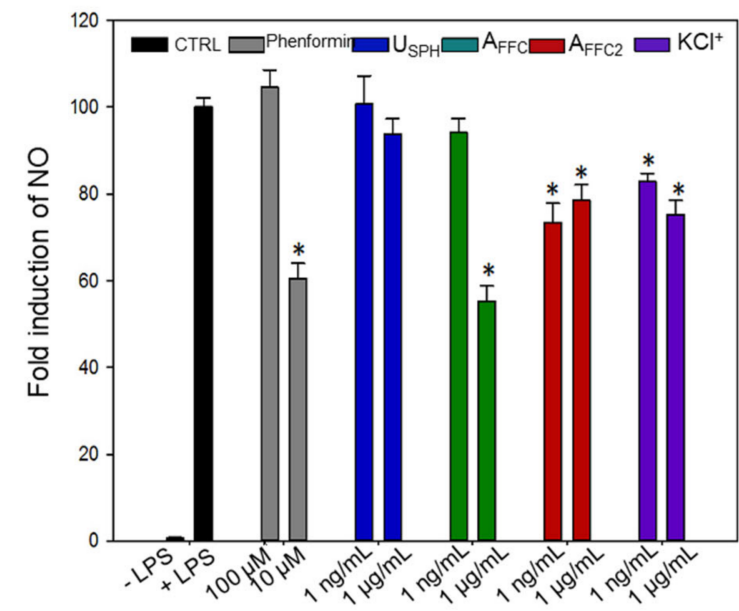

Figure 4. Inflammatory activity on J774 macrophages in absence or presence of LPS stimulation by (a) the recovery compartments from EDUF configuration 1 and (b) the recovery compartments from EDUF configuration 2. Data represent mean \pm SEM, $n=6$. An asterisk indicates that mean values are significantly different $(p<0.05)$ from the control's $(+\mathrm{LPS})$ mean value.

3.2. Peptide Sequence Identification and In-Vitro Experiments of Individual Synthesized Peptides 3.2.1. Peptide Sequence Identification

All these results suggested that anionic peptides have gluco-regulatory effects by enhancing the glucose uptake in L6 muscle cells and decreasing the glucose production in hepatic cells, while cationic peptides decreased the inflammation in activated macrophages. In order to identify potential bioactive peptides, both fractions were characterized by MS/MS analysis coupled with a database for identification. Fifty-three compounds were found to be common to all these fractions, and 24 potential sequences were successfully identified by database comparison (Salmonidae database downloaded from [37]). Amongst the 24 peptide potential sequences identified, 13 peptides were chosen based on their scores obtained by comparison of their experimental MS/MS spectra and their theoretical MS/MS spectra to be chemically synthesized. The sequences of the 13 peptides were listed in Table 1. Each synthesized peptide was tested individually for its in-vitro activities on glucose uptake, hepatic glucose production and anti-inflammatory. 
Table 1. Sequences and characteristics of synthesized peptides.

\begin{tabular}{|c|c|c|c|c|c|c|}
\hline Sequences Identified & Molecular Weight (Da) & Retention Time (min) & Net Charge (at pH 6) & pI & Scores * & $\%$ SPI ** \\
\hline IPVE & 456.2581 & 10.174 & - & 4.60 & 7.97 & 73.1 \\
\hline IVDI & 458.2738 & 22.342 & - & 3.80 & 6.6 & 78 \\
\hline IEGTL & 531.2890 & 17.270 & - & 4.00 & 9.93 & 77.3 \\
\hline LAFDHDL & 829.3972 & 24.588 & - & 4.19 & 10.19 & 79.3 \\
\hline LATNQHF & 829.3972 & 24.588 & + & 6.74 & 11.26 & 80,8 \\
\hline LVEPAĀGTI & 869.4857 & 18.700 & - & 3.99 & 7.74 & 77.9 \\
\hline LLTEAPLN & 869.4857 & 18.700 & - & 3.99 & 8.93 & 79.2 \\
\hline VAPEEHPTL & 991.4970 & 15.796 & - & 4.50 & 17.53 & 93.7 \\
\hline LDTDYL & 738.3424 & 40.044 & - & 3.56 & 8.26 & 81.3 \\
\hline ILLGMD & 660.3504 & 29.454 & - & 4.30 & 10.63 & 81.3 \\
\hline ITDYL & 623.3160 & 25.851 & - & 3.80 & 11.59 & 89.1 \\
\hline IGEEF & 593.2770 & 20.050 & - & 3.79 & 9.05 & 77.8 \\
\hline IDAGF & 521.2483 & 27.307 & - & 3.79 & 7.83 & 81.7 \\
\hline
\end{tabular}

* Score of an individual peptide. It reflects the information content in the MS/MS spectrum [38]. >15 (quality: outstanding) and combined with $\%$ SPI of 60 or greater, very likely to be valid. $>9$ (quality: good) and combined with $\%$ SPI of 60 or greater, likely to be valid. $>5$ (quality: mixed quality) and combined with a \% SPI of 60 or greater, review results to determine whether interpretation is valid. $* * \%$ SPI: percentage of the extracted MS/MS ion current explained by theoretical fragmentation of the database hit [38].

\subsubsection{Glucose Uptake}

For glucose uptake, all peptides were tested under basal conditions (Figure 5a,c) and in the presence of insulin (Figure $5 b, d$ ). No differences were observed in the basal condition whatever the peptide tested. While in the presence of insulin, IPVE demonstrated a significant enhancement of glucose uptake (17\%) compared to the insulin control $(p=0.016)$.
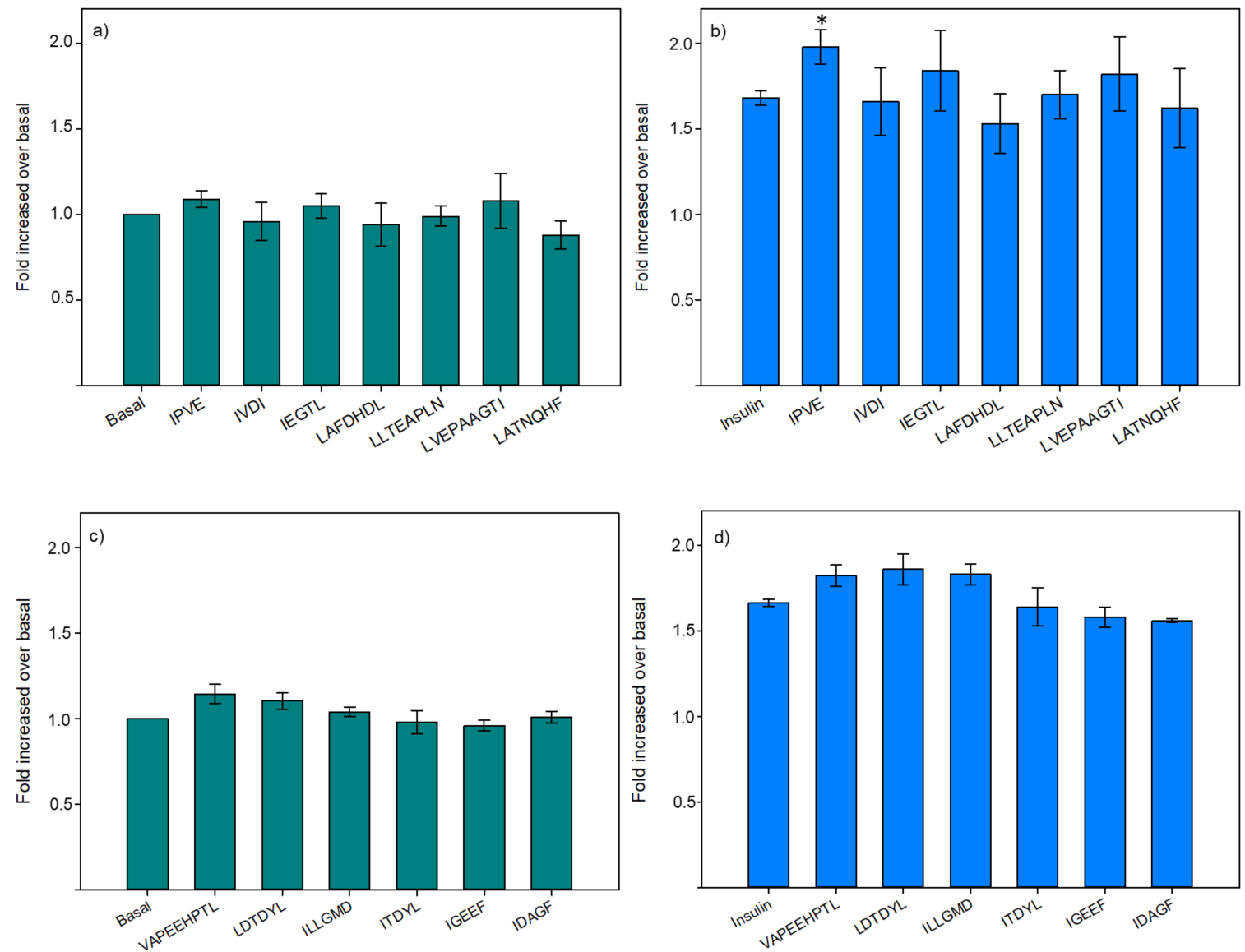

Figure 5. Effects of synthesized peptides on glucose uptake modulation in L6 skeletal muscle cells in basal (a,c) or insulinstimulated $(\mathbf{b}, \mathbf{d})$ conditions. Data are expressed as mean $\pm \mathrm{SEM}, n=9$. An asterisk indicates that mean values are significantly different $(p<0.05)$ from the control's mean value. 
Afterward, the dose-response effect to IPVE was tested (Figure 6) with concentrations from $1 \mu \mathrm{g} / \mathrm{mL}$ to $10 \mathrm{pg} / \mathrm{mL}$. These results confirmed the capacity of IPVE to improve glucose uptake in muscle cells, as it was able to increase the bioactivity at $10 \mathrm{ng} / \mathrm{mL}$ and $1 \mathrm{ng} / \mathrm{mL}$. Also, this result showed that the response of IPVE was dose-dependent, as for the highest $(>10 \mathrm{ng} / \mathrm{mL})$ and the lowest $(<100 \mathrm{pg} / \mathrm{mL})$ concentrations tested, IPVE presented no effect on glucose uptake. Although not spectacular, the effect of IPVE concentration is nonetheless constant and significant. It is also important to keep in mind that in the presence of insulin, the glucose transport is already highly stimulated in the muscle cell and that it can be then difficult to stimulate further the entry of glucose in a very marked way.
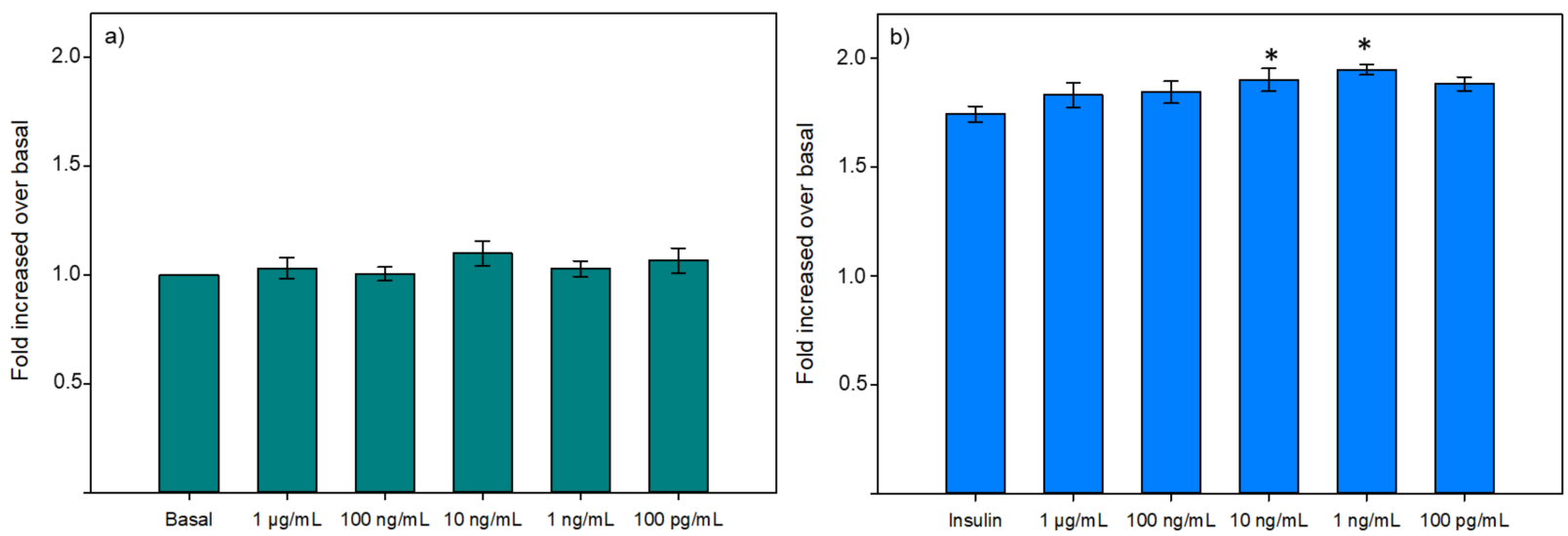

Figure 6. Dose-response effect of IPVE on glucose uptake modulation in L6 skeletal muscle cells in basal (a) or insulinstimulated (b) conditions. Data are expressed as mean $\pm \mathrm{SEM}, n=9$. An asterisk indicates that mean values are significantly different $(p<0.05)$ from the control's mean value.

\subsubsection{Hepatic Glucose Production}

For their capacity to decrease the HGP, all 13 peptides were tested in basal (Figure 7a,c) and insulin (Figure $7 \mathrm{~b}, \mathrm{~d}$ ) conditions. Concerning the first seven peptides (Figure 7a,b), results demonstrated no differences when tested under basal condition (Figure 7a). For the insulin condition, as the peptides were incubated with insulin at $0.1 \mathrm{nmol}$, the statistical comparisons were performed with the insulin control at $0.1 \mathrm{nmol}$. Two peptides demonstrated a decrease in their bioactivity when incubated with insulin. Indeed, IVDI and IEGTL have downregulated the HGP by $20 \%$ and $30 \%$, when compared to insulin at $0.1 \mathrm{nmol}$, respectively. Moreover, IEGTL incubated with insulin at $0.1 \mathrm{nmol}$ has shown the same capacity to decrease the HGP than insulin alone at $10 \mathrm{nmol}$. From the six remaining peptides (Figure 7c,d), VAPEEHPTL demonstrated a decrease of the HGP in basal $(20 \%)$ and insulin-stimulated (18\%) conditions.

\subsubsection{Inflammation}

All peptides were tested in the presence of LPS, to observe a possible reduction of the LPS-induced inflammatory effect. Moreover, phenformin, a commonly used antidiabetic drug for the treatment of T2D, was used to compare the effect of the peptides. According to these results, none of the peptides demonstrated a significant decrease of the NO production (Figure 8). However, as some fractions demonstrated a strong anti-inflammatory effect, the previous effect observed could be due to other peptides such as cationic peptides or due to an antagonistic effect among peptides. Recently, two new cationic peptide sequences (IVPAS and FDKPVSPLL) from herring milt hydrolysate were identified and demonstrated an in-vitro anti-inflammatory activity [29]. What is interesting here is that FDKPVSLL was present and identified in the $A_{F F C}$ and $C_{F F C 2}$ fractions and might explain their anti-inflammatory activity. 

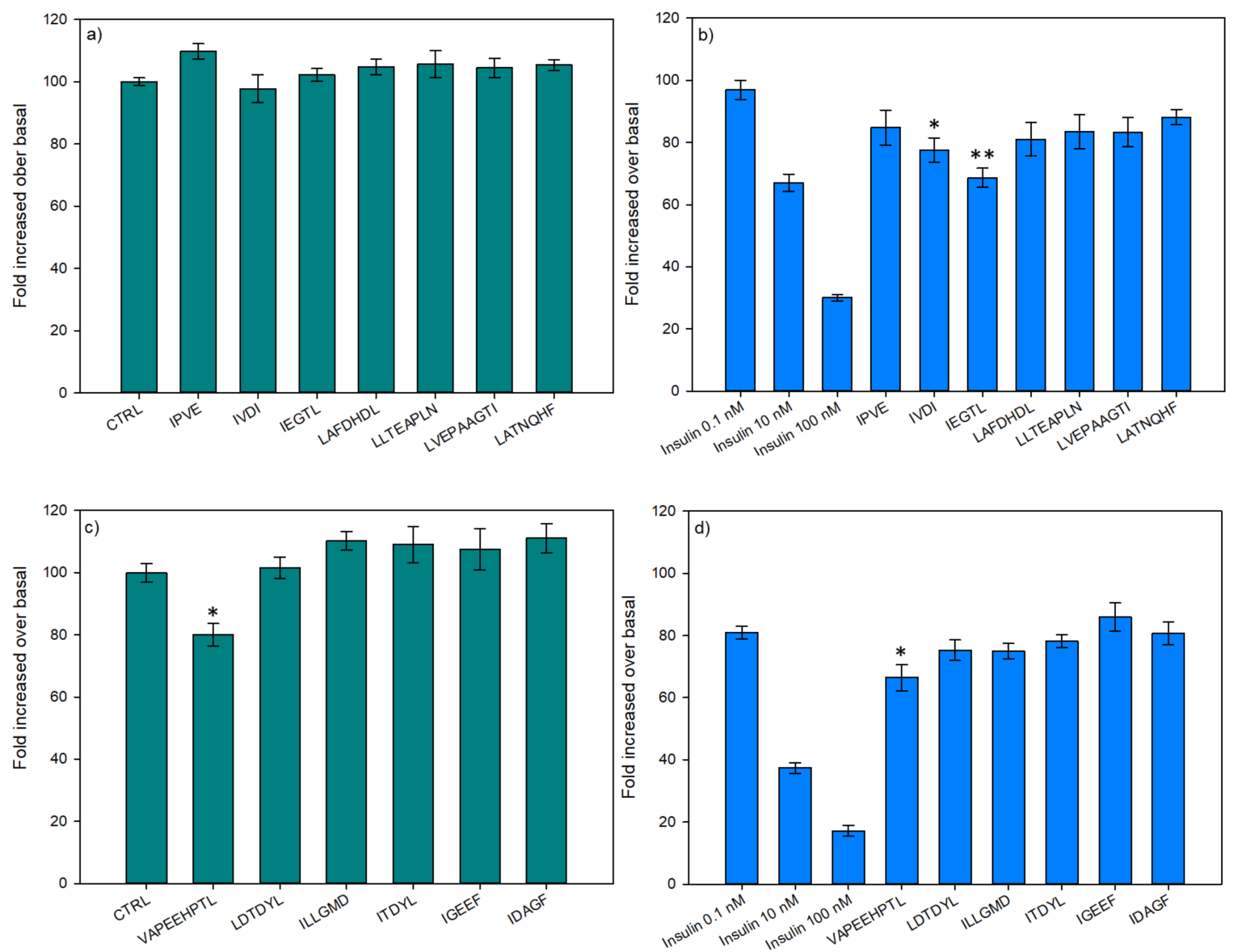

Figure 7. Effects of synthesized peptides on in-vitro hepatic production from FAO cells in basal (a,c) and insulin-stimulated $(\mathbf{b}, \mathbf{d})$ conditions, all at $1 \mathrm{ng} / \mathrm{mL}$. Data are expressed as mean $\pm \mathrm{SEM}, n=6$. An asterisk indicates that mean values are significantly different $(p<0.05)$ from the control's mean value. Two asterisks indicate that mean values are significantly different $(p<0.01)$ from the control's mean value.

Numerous studies reported in the literature demonstrated the beneficial effects of salmon proteins and hydrolysates on T2D, however, none of these studies were able to identify the peptide sequences responsible for these beneficial effects. Furthermore, as these peptides sequences are new concerning the bioactivities tested in the present study, no information is available in the literature. However, what can be observed, is that the identified peptides in this study are mostly composed of hydrophobic amino acids such as Ala (A), Gly (G), Ile (I), Leu (L), Pro (P) and Val (V). It was previously described that antidiabetic and anti-obesity peptides are generally hydrophobic [39]. A mixture of hydrophobic amino acids, mostly composed of Ile ( $2 \mathrm{mM})$, but also by Cys $(0.012 \mathrm{mM})$, Met $(0.006 \mathrm{mM})$, Val $(0.0016 \mathrm{mM})$ and Leu $(0.014 \mathrm{mM})$ demonstrated the capacity to increase, in basal and insulin-stimulated conditions, glucose uptake in isolated rat epitrochlearis muscle [40]. These effects appear to be mediated via a pathway that is independent from the usual insulin cascade and, therefore, may prove effective as an alternative therapeutic treatment for the insulin resistance [40]. Indeed, as reported by Mîinea et al. [41], insulin increases the AKT phosphorylation, which inactivates AS160 by its phosphorylation and then promotes GLUT4 translocation [41]. However, the AA mixture seemed to increase the AS160 phosphorylation, thus promoting GLUT4 translocation, independently of the AKT phosphorylation. In another study, three hydrophobic peptides (IAVPGEVA, IAVPTGVA and LPYP) identified from soy glycinin, were able to increase the glucose uptake in HepG2 cells in another way. In that case, the glucose uptake was increased via GLUT1 and GLUT4 activation, through the adenosine monophosphateactivated protein kinase (AMPK) signaling pathways via phosphorylation of AKT and 
AMPK [42]. Moreover, the phosphorylation of AMPK, as reported by Mîinea et al. [41], can inhibit the mTOR/p70S6K pathway; its inactivation was described as a novel modulator of insulin-stimulated glucose transport in skeletal muscle cells [28]. Interestingly, these three peptides have the same antidiabetic molecular mechanisms as drugs like metformin [43] and thiazolidinediones [42,44]. In addition, leucine has also demonstrated its glucose metabolism effects by stimulating the glycogen synthesis via the inactivation of glycogen synthase kinase-3 in L6 cells [45]. Finally, it was reported that dipeptides mostly composed by hydrophobic AAs, such as IV, LV, VL, II, LI, IL and LL, were able to increase glucose uptake in muscle cells via the PI3-kinase and PKC (protein kinase C) pathways [46]. It has also been observed that the PI 3-kinase-dependent PKC activation was diminished in muscle and liver during insulin resistance and T2D [47]. Nevertheless, to better understand, how IPVE, IVDI, IEGTL and VAPEEHPTL, promote glucose metabolism, further analyses must be carried out on the molecular mechanisms of these BPs. It could be interesting to test different molecular pathways such as AKT/AS160 or the AKT/AMPK pathways, previously described.

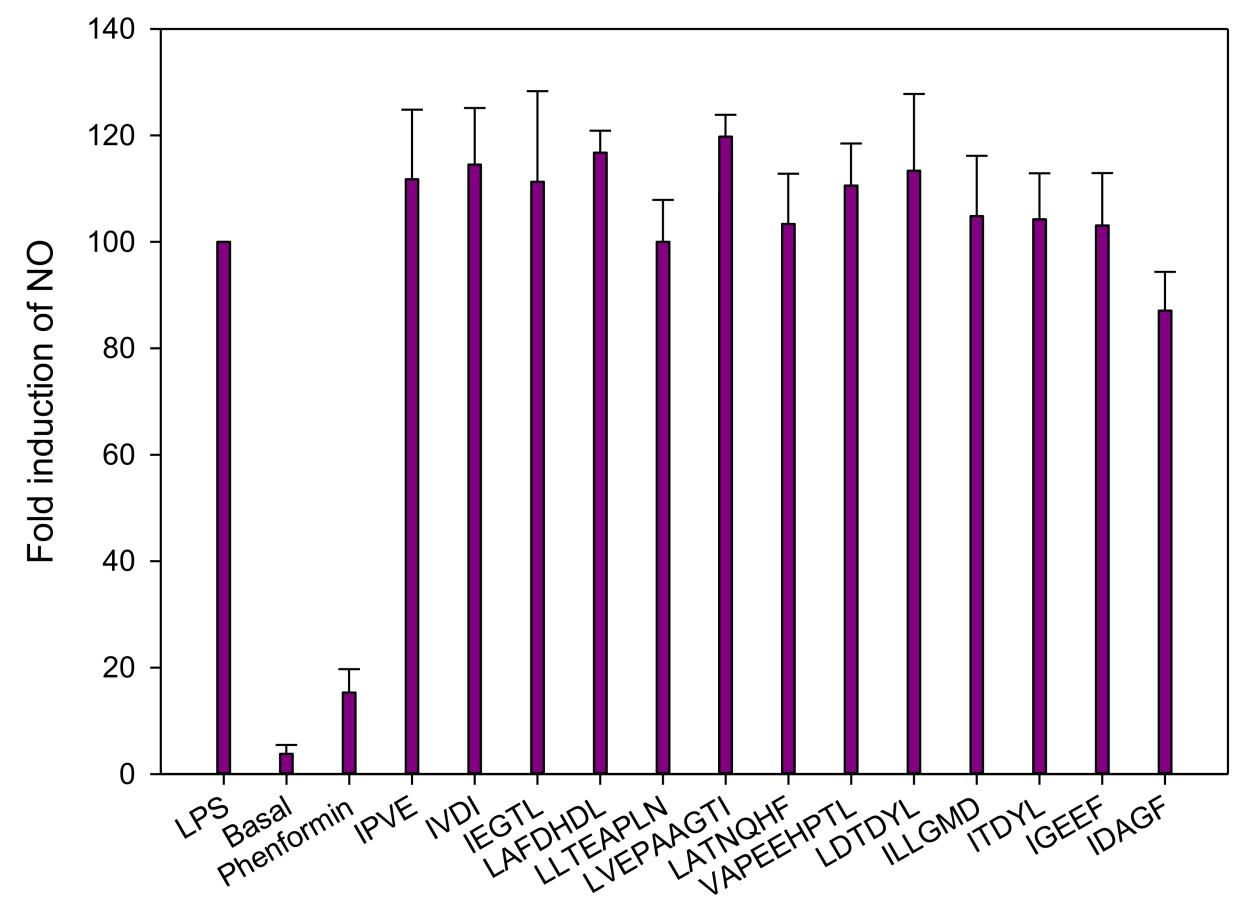

Figure 8. Effects of peptides on the nitric oxide (NO) production on lipopolysaccharide (LPS)-induced J774 macrophage cells. Data are expressed as mean \pm standard deviation, $n=4$.

Moreover, another critical aspect in the development of BPs as natural new therapeutic approaches is their bioavailability. The bioavailability of peptides is the quantity that passes through the mucosal membranes in the intestine and stays available for action within the cells [48]. This bioavailability is generally affected by their physicochemical properties such as molecular size, charge, sequence, and solubility [39,49]. Thus, this bioavailability is determined by their sensitivity to the digestive enzyme peptidase and intestinal absorption. In humans, the gastrointestinal digestion of peptides starts in the stomach by the action of pepsin, and it continues in the luminal phase of the small intestine by the action of pancreatic proteases trypsin, $\alpha$-chymotrypsin, elastase, and carboxypeptidase A and B [50]. These four BPs, as well as the EDUF fractions containing these peptides, were obtained by successive enzymatic digestion using three gastrointestinal enzymes: pepsin, trypsin, and chymotrypsin, and should not be affected by these gastrointestinal enzymes anymore. Nevertheless, if smaller peptides (di- or tri-peptides) can be transported across the enterocytes through intestinal-expressed peptide transporters (PEP1 and PEP2) [50], 
the transport of these oligopeptides through the intestine must be investigated. It was previously described that oligopeptides may be absorbed by passive transport through hydrophobic regions (transcellular transport) of membrane epithelia or tight junctions (paracellular transport) [51-53]. Additionally, hydrophobic peptides showed a higher permeation through biological membranes [39,50].

\section{Conclusions}

To the best of our knowledge, this is the first time that (1) peptide fractions generated after separation by EDUF were demonstrated as bioactive on three different bioactivities, all involved in the T2D, and (2) potential sequences involved in the improvement of glucose uptake and/or in the regulation of hepatic glucose production were identified from salmon by-product hydrolysates. Hence, two fractions were particularly promising: $\mathrm{A}_{\mathrm{FFC}}$ and $\mathrm{C}_{\mathrm{FFC} 2}$ since they were both able to (1) increase glucose uptake in L6 muscle cells in the presence of insulin, (2) decrease hepatic glucose production in hepatic cells in both basal and insulin conditions and (3) decrease LPS-induced inflammation in macrophages. Moreover, $\mathrm{A}_{\mathrm{FFC}}$, has shown an impressive capacity to decrease inflammation with a more important decrease than phenformin, a drug usually used to treat T2D. It also appeared from these results that anionic peptides concentrated in the $\mathrm{KCl}^{-}$were able to increase glucose uptake and decrease HGP, while cationic peptides concentrated in $\mathrm{KCl}^{+}$and present in both $\mathrm{A}_{\mathrm{FFC}}$ and $\mathrm{A}_{\mathrm{FFC} 2}$ have shown good anti-inflammatory properties. Nevertheless, it is more probable that these bioactivities result from a synergistic effect among peptides than the effect of just one peptide. Finally, four new BP sequences were identified (IPVE, IVDI, IEGTL, and VAPEEHPTL), and their glucoregulatory effects were demonstrated. Nevertheless, the molecular mechanisms and their bioavailability must be determined before being considered natural new therapeutic agents for treating T2D.

Author Contributions: Conceptualization, L.H., A.M. and L.B.; methodology, L.H., K.D.P., J.T. and L.B.; software, L.H. and J.T.; validation, L.H., G.P., A.M. and L.B.; formal analysis, L.H. and K.D.P.; investigation, L.H., A.M. and L.B.; resources, L.H., K.D.P., J.T., G.P., A.M. and L.B.; data curation, L.H., K.D.P. and J.T.; writing—original draft preparation, L.H.; writing—review and editing, L.H., G.P., J.T., T.G., A.M. and L.B.; visualization, L.H., G.P., A.M. and L.B.; supervision, A.M. and L.B.; project administration, L.B.; funding acquisition, L.B. All authors have read and agreed to the published version of the manuscript.

Funding: This work was supported by the "Conseil de recherches en sciences naturelles et en génie du Canada" (CRSNG), the Consortium de Recherche et Innovations en Bioprocédés Industriels au Québec (CRIBIQ) (Grant number 2013-018-C10), the Canadian Institutes for Health Research (CIHR) (Grant number FH4-129922). Authors would also thanks Mitacs for their financial supports by a Cluster grant program: Salmon peptide identification and purification and their insulin modulation.

Institutional Review Board Statement: Not applicable.

Informed Consent Statement: Not applicable.

Data Availability Statement: Data is contained within the article.

Acknowledgments: The authors are thankful to Bruno Marcotte and Marion Valle for their technical assistance. Authors would also like to thank Cooke Aquaculture for providing the salmon frames. Special gratitude goes to Jean-Philippe Songpadith for his help on the hepatic glucose production and anti-inflammatory experiments.

Conflicts of Interest: The authors declare no conflict of interest.

\section{References}

1. Prato, S.; Bianchi, C.; Daniele, G. Abnormalities of Insulin Secretion and $\beta$-Cell Defects in Type 2 Diabetes. In Textbook of Diabetes, 5th ed.; John Wiley \& Sons Ltd.: Chichester, UK, 2016; pp. 161-173, Chapter 12, Part 3.

2. Marteau, T.M.; Hollands, G.J.; Fletcher, P.C. Changing human behavior to prevent disease: The importance of targeting automatic processes. Science 2012, 337, 1492-1495. [CrossRef] [PubMed] 
3. World Health Organization. Global Action Plan for the Prevention and Control of Noncommunicable Diseases 2013-2020; World Health Organization: Geneva, Switzerland, 2013.

4. International Diabetes Federation. Atlas du Diabète de la FID; International Diabetes Federation: Brussels, Belgium, 2019.

5. Davì, G.; Santilli, F.; Patrono, C. Nutraceuticals in diabetes and metabolic syndrome. Cardiovasc. Ther. 2010, 28, 216-226. [CrossRef]

6. Daviglus, M.L.; Stamler, J.; Orencia, A.J.; Dyer, A.R.; Liu, K.; Greenland, P.; Walsh, M.K.; Morris, D.; Shekelle, R.B. Fish consumption and the 30-year risk of fatal myocardial infarction. N. Engl. J. Med. 1997, 336, 1046-1053. [CrossRef] [PubMed]

7. Nkondjock, A.; Receveur, O. Fish-seafood consumption, obesity, and risk of type 2 diabetes: An ecological study. Diabetes Metab. 2003, 29, 635-642. [CrossRef]

8. Friedberg, C.E.; Janssen, M.J.; Heine, R.J.; Grobbee, D.E. Fish oil and glycemic control in diabetes: A meta-analysis. Diabetes Care 1998, 21, 494-500. [CrossRef]

9. Feskens, E.J.; Bowles, C.H.; Kromhout, D. Inverse association between fish intake and risk of glucose intolerance in normoglycemic elderly men and women. Diabetes Care 1991, 14, 935-941. [CrossRef]

10. Tremblay, F.; Lavigne, C.; Jacques, H.; Marette, A. Dietary cod protein restores insulin-induced activation of phosphatidylinositol 3-kinase/Akt and GLUT4 translocation to the T-tubules in skeletal muscle of high-fat-fed obese rats. Diabetes 2003, 52, 29-37. [CrossRef] [PubMed]

11. Tremblay, F.; Jacques, H.; Marette, A. Modulation of insulin action by dietary proteins and amino acids: Role of the mammalian target of rapamycin nutrient sensing pathway. Curr. Opin. Clin. Nutr. Metab. Care 2005, 8, 457-462. [CrossRef]

12. Lavigne, C.; Tremblay, F.; Asselin, G.; Jacques, H.; Marette, A. Prevention of skeletal muscle insulin resistance by dietary cod protein in high fat-fed rats. Am. J. Physiol. Endocrinol. Metab. 2001, 281, E62-E71. [CrossRef] [PubMed]

13. Tremblay, F.; Lavigne, C.; Jacques, H.; Marette, A. Role of dietary proteins and amino acids in the pathogenesis of insulin resistance. Annu. Rev. Nutr. 2007, 27, 293-310. [CrossRef] [PubMed]

14. Ouellet, V.; Marois, J.; Weisnagel, S.J.; Jacques, H. Dietary cod protein improves insulin sensitivity in insulin-resistant men and women: A randomized controlled trial. Diabetes Care 2007, 30, 2816-2821. [CrossRef]

15. Ouellet, V.; Weisnagel, S.J.; Marois, J.; Bergeron, J.; Julien, P.; Gougeon, R.; Tchernof, A.; Holub, B.J.; Jacques, H. Dietary cod protein reduces plasma C-reactive protein in insulin-resistant men and women. J. Nutr. 2008, 138, 2386-2391. [CrossRef]

16. Pilon, G.; Ruzzin, J.; Rioux, L.-E.; Lavigne, C.; White, P.J.; Frøyland, L.; Jacques, H.; Bryl, P.; Beaulieu, L.; Marette, A. Differential effects of various fish proteins in altering body weight, adiposity, inflammatory status, and insulin sensitivity in high-fat-fed rats. Metabolism 2011, 60, 1122-1130. [CrossRef] [PubMed]

17. Chevrier, G.; Mitchell, P.L.; Rioux, L.-E.; Hasan, F.; Jin, T.; Roblet, C.R.; Doyen, A.; Pilon, G.; St-Pierre, P.; Lavigne, C.; et al Low-molecular-weight peptides from salmon protein prevent obesity-linked glucose intolerance, inflammation, and dyslipidemia in LDLR - / - / ApoB100/100 mice. J. Nutr. 2015, 145, 1415-1422. [CrossRef] [PubMed]

18. Danquah, M.K.; Agyei, D. Pharmaceutical applications of bioactive peptides. OA Biotechnol. 2012, 1, 1-7. [CrossRef]

19. Li-Chan, E.C.Y. Bioactive peptides and protein hydrolysates: Research trends and challenges for application as nutraceuticals and functional food ingredients. Curr. Opin. Food Sci. 2015, 1, 28-37. [CrossRef]

20. del Mar Contreras, M.; Lpez-Expsito, I.; Hernndez-Ledesma, B.; Ramos, M.; Recio, I. Application of mass spectrometry to the characterization and quantification of food-derived bioactive peptides. J. AOAC Int. 2008, 91, 981-994. [CrossRef]

21. Henaux, L.; Thibodeau, J.; Pilon, G.; Gill, T.; Marette, A.; Bazinet, L. How Charge and Triple Size-Selective Membrane Separation of Peptides from Salmon Protein Hydrolysate Orientate their Biological Response on Glucose Uptake. Int. J. Mol. Sci. 2019, 20, 1939. [CrossRef]

22. Roden, M.; Petersen, K.; Shulman, G. Insulin resistance in type 2 diabetes. In Textbook of Diabetes; John Wiley \& Sons, Ltd. Publishers: Hoboken, NJ, USA, 2017; pp. 174-186.

23. Fields, G.B.; Noble, R.L. Solid phase peptide synthesis utilizing 9-fluorenylmethoxycarbonyl amino acids. Int. J. Pept. Protein Res. 1990, 35, 161-214. [CrossRef]

24. Hammami, R.; Bédard, F.; Gomaa, A.; Subirade, M.; Biron, E.; Fliss, I. Lasso-inspired peptides with distinct antibacterial mechanisms. Amino Acids 2015, 47, 417-428. [CrossRef] [PubMed]

25. Bollhagen, R.; Schmidberger, M.; Barlos, K.; Grelle, E. A new reagent for the cleavage of fully protected peptides synthesised on 2-chlorotrityl chloride resin. J. Chem. Soc. Chem. Commun. 1994, 22, 2559-2560. [CrossRef]

26. Suwal, S.; Roblet, C.; Amiot, J.; Bazinet, L. Presence of free amino acids in protein hydrolysate during electroseparation of peptides: Impact on system efficiency and membrane physicochemical properties. Sep. Purif. Technol. 2015, 147, 227-236. [CrossRef]

27. Roblet, C.; Doyen, A.; Amiot, J.; Pilon, G.; Marette, A.; Bazinet, L. Enhancement of glucose uptake in muscular cell by soybean charged peptides isolated by electrodialysis with ultrafiltration membranes (EDUF): Activation of the AMPK pathway. Food Chem. 2014, 147, 124-130. [CrossRef]

28. Tremblay, F.; Marette, A. Amino acid and insulin signaling via the mTOR/p70 S6 kinase pathway-A negative feedback mechanism leading to insulin resistance in skeletal muscle cells. J. Biol. Chem. 2001, 276, 38052-38060. [CrossRef] [PubMed]

29. Durand, R.; Fraboulet, E.; Marette, A.; Bazinet, L. Simultaneous double cationic and anionic molecule separation from herring milt hydrolysate and impact on resulting fraction bioactivities. Sep. Purif. Technol. 2019, 210, 431-441. [CrossRef]

30. Eckel, R.H.; Grundy, S.M.; Zimmet, P.Z. The metabolic syndrome. Lancet 2005, 365, 1415-1428. [CrossRef]

31. Martínez-Maqueda, D.; Miralles, B.; Recio, I.; Hernández-Ledesma, B. Antihypertensive peptides from food proteins: A review. Food Funct. 2012, 3, 350-361. [CrossRef] [PubMed] 
32. Korhonen, H.; Pihlanto, A. Bioactive peptides: Production and functionality. Int. Dairy J. 2006, 16, 945-960. [CrossRef]

33. Roblet, C.; Akhtar, M.J.; Mikhaylin, S.; Pilon, G.; Gill, T.; Marette, A.; Bazinet, L. Enhancement of glucose uptake in muscular cell by peptide fractions separated by electrodialysis with filtration membrane from salmon frame protein hydrolysate. J. Funct. Foods 2016, 22, 337-346. [CrossRef]

34. Durand, R.; Pellerin, G.; Thibodeau, J.; Fraboulet, E.; Marette, A.; Bazinet, L. Screening for metabolic syndrome application of a herring by-product hydrolysate after its separation by electrodialysis with ultrafiltration membrane and identification of novel anti-inflammatory peptides. Sep. Purif. Technol. 2020, 235, 116205. [CrossRef]

35. Kadel, S.; Daigle, G.; Thibodeau, J.; Perreault, V.; Pellerin, G.; Lainé, C.; Bazinet, L. How physicochemical properties of filtration membranes impact peptide migration and selectivity during electrodialysis with filtration membranes: Development of predictive statistical models and understanding of mechanisms involved. J. Membr. Sci. 2021, 619, 118175. [CrossRef]

36. Suwal, S.; Roblet, C.; Doyen, A.; Amiot, J.; Beaulieu, L.; Legault, J.; Bazinet, L. Electrodialytic separation of peptides from snow crab by-product hydrolysate: Effect of cell configuration on peptide selectivity and local electric field. Sep. Purif. Technol. 2014, 127, 29-38. [CrossRef]

37. NCBI. Available online: https:/ / www.ncbi.nlm.nih.gov/protein/?term=salmonidae (accessed on 11 July 2018).

38. Agilent Technologies. Agilent G2721AA/G2733AA Spectrum Mill MS Proteomics Workbench: User Guide; Agilent Technologies: Santa Clara, CA, USA, 2012.

39. Pangestuti, R.; Kim, S.-K. Bioactive peptide of marine origin for the prevention and treatment of non-communicable diseases. Mar. Drugs 2017, 15, 67. [CrossRef] [PubMed]

40. Kleinert, M.; Liao, Y.-H.; Nelson, J.L.; Bernard, J.R.; Wang, W.; Ivy, J.L. An amino acid mixture enhances insulin-stimulated glucose uptake in isolated rat epitrochlearis muscle. J. Appl. Physiol. 2011, 111, 163-169. [CrossRef]

41. Mîinea, C.P.; Sano, H.; Kane, S.; Sano, E.; Fukuda, M.; Peränen, J.; Lane, W.S.; Lienhard, G.E. AS160, the Akt substrate regulating GLUT4 translocation, has a functional Rab GTPase-activating protein domain. Biochem. J. 2005, 391, 87-93. [CrossRef]

42. Lammi, C.; Zanoni, C.; Arnoldi, A. Three peptides from soy glycinin modulate glucose metabolism in human hepatic HepG2 cells. Int. J. Mol. Sci. 2015, 16, 27362-27370. [CrossRef] [PubMed]

43. Turban, S.; Stretton, C.; Drouin, O.; Green, C.J.; Watson, M.L.; Gray, A.; Ross, F.; Lantier, L.; Viollet, B.; Hardie, D.G. Defining the contribution of AMP-activated protein kinase (AMPK) and protein kinase $\mathrm{C}$ (PKC) in regulation of glucose uptake by metformin in skeletal muscle cells. J. Biol. Chem. 2012, 287, 20088-20099. [CrossRef]

44. Brunmair, B.; Staniek, K.; Gras, F.; Scharf, N.; Althaym, A.; Clara, R.; Roden, M.; Gnaiger, E.; Nohl, H.; Waldhäusl, W. Thiazolidinediones, like metformin, inhibit respiratory complex I: A common mechanism contributing to their antidiabetic actions? Diabetes 2004, 53, 1052-1059. [CrossRef]

45. Peyrollier, K.; Hajduch, E.; Blair, A.S.; Hyde, R.; Hundal, H.S. L-leucine availability regulates phosphatidylinositol 3-kinase, p70 S6 kinase and glycogen synthase kinase-3 activity in L6 muscle cells: Evidence for the involvement of the mammalian target of rapamycin (mTOR) pathway in the L-leucine-induced up-regulation of system A amino acid transport. Biochem. J. 2000, 350, 361-368. [PubMed]

46. Morifuji, M.; Koga, J.; Kawanaka, K.; Higuchi, M. Branched-chain amino acid-containing dipeptides, identified from whey protein hydrolysates, stimulate glucose uptake rate in L6 myotubes and isolated skeletal muscles. J. Nutr. Sci. Vitaminol. 2009, 55, 81-86. [CrossRef]

47. Schmitz-Peiffer, C.; Biden, T.J. Protein kinase $C$ function in muscle, liver, and $\beta$-cells and its therapeutic implications for type 2 diabetes. Diabetes 2008, 57, 1774-1783. [CrossRef] [PubMed]

48. Shahidi, F.; Chandrasekara, A. Millet grain phenolics and their role in disease risk reduction and health promotion: A review. J. Funct. Foods 2013, 5, 570-581. [CrossRef]

49. Udenigwe, C.C.; Aluko, R.E. Food protein-derived bioactive peptides: Production, processing, and potential health benefits. J. Food Sci. 2012, 77, R11-R24. [CrossRef]

50. Darewicz, M.; Dziuba, B.; Minkiewicz, P.; Dziuba, J. The preventive potential of milk and colostrum proteins and protein fragments. Food Rev. Int. 2011, 27, 357-388. [CrossRef]

51. Pauletti, G.M.; Gangwar, S.; Knipp, G.T.; Nerurkar, M.M.; Okumu, F.W.; Tamura, K.; Siahaan, T.J.; Borchardt, R.T. Structural requirements for intestinal absorption of peptide drugs. J. Control. Release 1996, 41, 3-17. [CrossRef]

52. Witt, K.A.; Davis, T.P. CNS drug delivery: Opioid peptides and the blood-brain barrier. AAPS J. 2006, 8, E76-E88. [CrossRef] [PubMed]

53. Salamat-Miller, N.; Johnston, T.P. Current strategies used to enhance the paracellular transport of therapeutic polypeptides across the intestinal epithelium. Int. J. Pharm. 2005, 294, 201-216. [CrossRef] 